$7 \%$ rise in average precipitation.

The effects of such an increase in temperature could be serious. The committee notes that there would be a poleward shift in the world's agricultural zones, marked changes in the location and extent of arid and semiarid zones, and potentially serious changes in regions of precipitation. For the north American breadbasket, for example, the effect could be to push the corn belt northwards off the productive soils of the midwest and on to poorer Canadian soils. The impact on the oceans could be even more severe. A warming of the surface layers could be expected, which would reduce vertical circulation, thereby reducing the biological productivity of the oceans because it would depress the circulation of nutrients. There would also be a significant shift in the location of the major fisheries.

A five-degree warming of the upper $1,000 \mathrm{~m}$ of ocean water would also raise the ocean level by simple expansion by about $1 \mathrm{~m}$. Meliting of sea ice would augment the rise in ocean level. As for the potential impact on the polar ice caps, the committee states that "in the present state of understanding, it is impossible to forecast what might happen to the Greenland and Antarctic ice caps". Since temperatures over the ice caps would be expected to remain below the freezing point, however, "melting at or near the surface of the ice probably would not occur". But increased precipitation associated with increased levels of carbon dioxide could lead to substantial increase in ice thickness, which in turn could cause severe stresses at the base of the ice caps and surges and slides of ice into the sea. "If these surges resulted in destruction of the west Antarctic ice cap, there might be a corresponding rise in sea level of about $5 \mathrm{~m}$ within 300 years", the committee notes.

The report does not consider in detail the potential impact of global warming on regional weather patterns, climatic variability and shifts in ocean currents because of the difficulty predicting such effects.

The committee's chief recommendation is that a major research effort should be instituted, on a worldwide basis, to address some of the major unknowns in the climatic models and measurements on which the projections are based. Such an effort could cost between $\$ 20$ and $\$ 100$ million a year, Revelle suggested last week.

The report's chief impact, however, is likely to be on discussions of energy policy. The committee notes that if the potential for climatic change is substantiated, it may be necessary to reverse the trend of consumption of fossil fuels. The committee adds: "In

\section{Jupiter success}

THANks to an intense lobbying effort by space scientists, university administrators and Governor Jerry Brown of California, the Jupiter Orbiter Probe, a key space science project, has survived a strong challenge in Congress. The House of Representatives last week rejected a recommendation from its powerful appropriations committee that the project should be killed, and voted funds to begin building the spacecraft next year. Since the Senate had already approved the project, the House vote constitutes the final goahead.

The Congressional debate over the Jupiter project provides an object lesson in the politics of big science. It also demonstrates the power that the scientific community can muster when it unites behind a major project.

Long considered a top priority space science mission, the Jupiter Orbiter Probe will involve the launch in January 1982 of twin spacecraft to orbit Jupiter and send scientific instruments into the planet's atmosphere. The total cost is expected to be close to $\$ 300$ million. Though the project has been on the drawing board for several years, this is the first year that the National Aeronautics and Space Administration (NASA) has asked Congress for funds to begin building hardware.

NASA officials were not anticipating much opposition to the project from Congress, and they consequently received a shock earlier this year when a House appropriations subcommittee, chaired by Edward Boland of Massachusetts, recommended that all funds for the mission be deleted from NASA's budget. The subcommittee's action, which was later upheld by the full appropriations committee and the House itself, was based on the fact that NASA was also requesting funds to begin building the Large Space Telescope. The subcommittee said that it would be willing to sanction only one major space science project, and it opted for the telescope.

Once the subcommittee's vote against the project was made known, the scientific community mobilised to reverse the decision. A flood of letters and telephone calls descended on

the face of so much uncertainty regarding climatic change, it may be argued that the wisest attitude would be laissez faire. Unfortunately, it will take a millennium for the effects of a century members of the Senate appropriations committee in an attempt to persuade the Senate to keep funds for the Jupiter project in its version of the NASA budget bill. The lobbying was successful, and it was then widely expected that when differences between the House and Senate versions of the budget bill were ironed. Out by a House-Senate conference committee, the Jupiter project would emerge with sufficient money to meet the launch schedule. But further problems arose.

House members of the conference committee refused to compromise on the project, insisting that it must be dropped in order to provide more money for higher priority efforts. Senate conferees, similarly, insisted that the project be allowed to proceed. To break the deadlock, the matter was referred back to the House for a separate vote last week. The lobbying was at its most intense shortly before the House vote.

The Jupiter Orbiter Probe is the only planetary project up for approval, and NASA officials thus argued that if it were killed there would be a major hiatus in planetary research. Abandoning the project would result in breaking up teams of scientists and engineers who have been working on planetary programmes, and continuity from one project to another would be lost, NASA officials argued. Moreover, since there would not be another suitable launch window until 1987, denial of funds for the project this year would effectively put Jupiter out of reach for another five years.

The chief political asset for the project, however, was the fact that it will be based at the Jet Propulsion Laboratory in California, a state with a large Congressional delegation and considerable political muscle. Alarmed at the prospect of losing a $\$ 300 \mathrm{mil}$ lion federal project, Governor Brown telephoned a number of Congressmen before last week's vote and urged them to support the project. As a result, the California delegation united with other supporters of the project, and the opposition of the appropriations subcommittee was easily overcome. The vote in the end was 131 to 280 .

Colin Norman

of fossil fuels to dissipate. If the decision is postponed until the impact of man-made climate changes has been felt, then, for all practical purposes, the die will already have been cast". $\square$ 